\title{
Pengaruh Model Pembelajaran Problem Based Learning dalam Meningkatkan Sikap Demokratis Mahasiswa
}

\author{
Daulat Nathanael Banjarnahor ${ }^{*}$ \\ Dosen Program Studi PKN, Universitas HKBP Nommensen Pematangsiantar \\ *Email: daulatnb@gmail.com \\ DOI: https://doi.org/10.33369/pendipa.5.3.316-321
}

\begin{abstract}
The purpose of this study was to describe: 1) How to implement civic education and learning to develop a democratic attitude and learning participation; 2) How to design a civic education learning model based on controversial issues in the mass media to develop a democratic attitude and student learning participation; 3) Based on the public To what extent can the civic education learning model of media controversial issues develop democratic attitudes and student participation in learning? It is indeed necessary to consider adopting appropriate learning methods to improve and discover students' understanding of the knowledge conveyed by the teacher. Learning model Problem-based learning or problem-based learning is a studentoriented or student-centered learning model. Problem-based learning models have methods to deal with real-life problems, and this learning emphasizes problem-solving investigation activities. This research is a scientific paper. When using a problem-based learning learning model, a descriptive qualitative research method with a phenomenological description type is used to describe the learning process extensively and deeply. By paying attention to and analyzing the focus of reality or field experience that occurs on the research object. The object of the study is the students of HKBP Nommensen Pematangsiantar University, and the standard of study is the students participating in the civic education seminar.
\end{abstract}

Keywords: Problem based learning model, Civic education, Democracy.

\begin{abstract}
ABSTRAK
Tujuan penelitian ini adalah untuk mendeskripsikan: 1) Bagaimana melaksanakan pendidikan dan pembelajaran kewarganegaraan untuk mengembangkan sikap demokratis dan partisipasi belajar; 2) Bagaimana merancang model pembelajaran PKn berbasis isu-isu kontroversial di media massa untuk mengembangkan sikap demokratis dan partisipasi belajar siswa; 3) Berbasis publik Sejauh mana model pembelajaran PKn dari isu kontroversial media mengembangkan sikap demokratis dan partisipasi siswa dalam pembelajaran? Memang perlu mempertimbangkan untuk mengadopsi metode pembelajaran yang tepat untuk meningkatkan dan menemukan pemahaman siswa tentang pengetahuan yang disampaikan oleh guru. Model Pembelajaran Pembelajaran berbasis masalah atau problem based learning merupakan model pembelajaran yang berorientasi pada siswa atau berpusat pada siswa. Model pembelajaran berbasis masalah mempunyai metode untuk menangani masalah kehidupan nyata, dan pembelajaran ini menekankan pada kegiatan investigasi pemecahan masalah. Penelitian ini merupakan karya tulis ilmiah. Pada saat menggunakan model pembelajaran berbasis masalah, metode penelitian kualitatif deskriptif dengan tipe deskripsi fenomenologi digunakan untuk mendeskripsikan proses pembelajaran secara luas dan mendalam. Dengan memperhatikan dan menganalisis fokus realitas atau pengalaman lapangan yang terjadi pada objek penelitian. Objek penelitian adalah mahasiswa HKBP Universitas Nommensen Pematangsiantar, dan standar studinya adalah mahasiswa peserta seminar PKn.
\end{abstract}

Kata kunci: Model pembelajaran problem based learning, Pkn, Demokrasi. 


\section{PENDAHULUAN}

Pendidikan merupakan pengalaman hidup selama proses pembelajaran. Semua pembelajaran yang penting bisa menjawab benar dan salah dari setiap kejadian. Dalam kematangan setiap manusia, metode atau teknologi tertentu digunakan, dan metode atau teknologi tersebut dapat digunakan melalui kursus tertentu. Pendidikan dimulai dari dalam keluarga, di masyarakat memperoleh pendidikan tentang bagaimana mengikuti perkembangan kehidupan dan pembentukan kepribadian yang diajarkan kepada keturunannya oleh orang tua. Ketika tiba saatnya memasuki dunia pendidikan, orang tua akan memulai pembelajaran formal di sekolahsekolah tertentu. Dengan berjalannya waktu, ketika di bangku kuliah, remaja memiliki jangkauan pendidikan keluarga menjadikan pembelajaran lebih luas, karena lingkungan menuntut dirinya untuk bersosialisasi.

Suwardjono (2005) mengemukakan bahwa kondisi pengajaran dan perilaku akademik perguruan tinggi di Indonesia secara keseluruhan tidak dapat diubah secara signifikan, hal ini terlihat dari sikap mahasiswa atau lulusan perguruan tinggi yang tidak melakukan tindakan atau pengalaman. Terbukti dengan kualitas penalaran dan pemahaman siswa dalam ujian komprehensif. Sulistio (2008) mengemukakan bahwa standar kompetensi merupakan kombinasi komprehensif dari hard skill dan soft skill yang dimiliki oleh siswa. Hard skill meliputi: penguasaan informasi bidang sains, penguasaan soft media text lisan dan tulisan, kemampuan analisis dan berpikir logis, kemampuan kerjasama tim dan kemampuan bekerja secara mandiri. Wang et al., (2005) juga mengetahui dalam bukunya bahwa ada permintaan yang besar untuk pendidikan teknik sederhana, terutama berfokus pada isu-isu yang berkaitan dengan sikap dan keterampilan yang dibutuhkan siswa untuk menjadi lulusan. Menurut Siahaan et al., (2020)Model pembelajaran Quantum Learning merupakan pembaruan pembelajaran yang memenuhi semua perbedaan yang mengoptimalkan momen pembelajaran. Dukung upaya reformasi ini untuk mengubah lingkungan belajar dengan mengurangi format kuliah tradisional dan meningkatkan inisiatif utama dan kreatif melalui pembelajaran aktif dan PBL.

Secara teoritis, Pendidikan

Kewarganegaraan dirancang sebagai mata pelajaran yang mengandung dimensi kognitif, afektif, dan psikomotorik yang saling bertautan atau saling berwawasan dan terintegrasi ke dalam konteks substansi gagasan, nilai, konsep, moralitas pancasila, kewarganegaraan demokratis, dan bela negara. Secara programatik, PKn dipahami sebagai mata pelajaran yang mengutamakan konten yang memasukkan nilai-nilai pembelajaran dan pengalaman dalam bentuk berbagai perilaku yang perlu diwujudkan dalam kehidupan seharihari (Budimansyah, 2008)). Berdasarkan Untuk mengembangkan kemampuannya, warga negara perlu mempelajari tiga komponen utama, yaitu pengetahuan kewarganegaraan, keterampilan kewarganegaraan dan karakter kewarganegaraan.

Pendidikan sipil yang berpusat pada masalah (pendidikan kewarganegaraan) dan pendidikan ilmu sosial (PIPS) (pendidikan yang berpusat pada masalah), dan dalam kerangka filosofi rekonstruksionis. Carole L. Hahn (Shaver, 1991: 470) menyatakan "Social research educators have long asserted that research and discussion of issues are important to democracy". Pendidikan Ilmu Pengetahuan Sosial dan Pendidikan Kewarganegaraan membelajarkan siswa untuk mampu memecahkan masalah-masalah sosial, dan isuisu kontroversial kebijakan publik, berada pada tradisi reflektif inquiry. Karakter kewarganegaraan merupakan sikap dan kebiasaan berpikir warganegara yang menopang berkembangnya fungsi sosial secara sehat dan jaminan kepentingan umum dari sistem demokrasi. Civic disposition adalah "... Civic attitudes and habits that are conducive to the healthy operation of democratic systems and common interests ". Secara konseptual civic disposition meliputi sejumlah karakteristik kepribadian, yakni "Civility (respect and civil discourse), individual responsibility, selfdiscipline, civic-mindedness, openmindedness, openness, skepticism, recognition of ambiguity), compromise (conflict of principles, compassion, generosity, and loyalty to the nation and its principles" (Quigley, Buchanan, dan 
Bahmueller, 1991: 13-14). Dengan kata lain tradisi ini memusatkan perhatian pada pengembangan karakter warganegara yang baik dengan ciri pokoknya mampu mengambil keputusan.dalam konteks sosial-politik. Namun dalam filsafat ilmu memiliki ontologi utama ilmu politik, terutama konsep "demokrasi politik" dalam pengertian "tanggung jawab dan hak warga negara" (Chreshore: 1886). Secara epistemologis, kewarganegaraan sebagai bidang keilmuan merupakan perkembangan salah satu dari lima tradisi "penelitian sosial", yaitu "penyebaran kewarganegaraan" (Barr, Barrt, dan Shermis:1978). Dikemukakan pula oleh Winataputra (2001) Saat ini tradisi tersebut berkembang pesat menjadi yang dikenal dengan "sistem pengetahuan" dan berparadigma sistem, di antaranya adalah "pendidikan kewarganegaraan" memiliki tiga bidang, yaitu: bidang akademik, bidang kurikulum, dan bidang sosial budaya.

Pendidikan Nasional memiliki tujuan menurut Undang-Undang No. 20 Tahun 2003 pasal 3 menyebutkan bahwa "Untuk berkembangnya potensi peserta didik agar menjadi pribadi yang beriman dan bertaqwa kepada Tuhan Yang Maha Esa, berakhlak mulia, sehat, berilmu, cakap, kreatif, mandiri, dan menjadi warga negara yang demokratis dan bertanggungjawab". Dari penjelasan tersebut aspek psikomotorik dan emosional juga menjadi prioritas dalam tujuan pendidikan nasional hanya aspek kognitif. Dengan demikian pendidikan nasional dapat diartikan bertujuan untuk menyeimbangkan hasil belajar peserta didik di sekolah dengan perilaku dalam keluarga maupun di masyarakat. Masalah-masalah kewarganegaraan terdapat beberapa contoh seperti korupsi, kolusi , nepotisme, HAM dan SARA. Masalah-masalah tersebut membutuhkan pemikiran-pemikiran dengan diskusi antar teman, guru dan pandangan masyarakat. Pembelajaran didalam kelas dapat diterapkan model Problem Based Learning dengan harapan ide-ide atau pemesahan masalah tentang kewarganegaraan dapat terpecahkan. Kita perlu usahakan terwujudnya Demokrasi Indonesia dengan sungguh-sungguh karna hal tersebut dapat berpengaruh pada pencapaian tujuan Nasional Bangsa Indonesia. Yaitu terwujudnya masyarakat yang adil dan makmur berdasarkan
Pancasila sebagai negara kesatuan di Indonesia adalah negara yang merdeka dan berdaulat yang mampu membangun kehidupan sosial yang sejahtera, sehingga dibutuhkan negara dengan sistem demokrasi. Dalam Sayidiman (2014) Demokrasi Indonesia merupakan kekuasaan dan kedaulatan ada di tangan rakyat, dilakukansesuai dengan dasar Negara Pancasila karena pancasila merupakan kepribadian bangsa Indonesia. Hal ini dapat diatasi dengan penerapan pembelajaran dan penerapan model pembelajaran yang tepat sangat perlu diperhatikan guna membantu mengetahui pemahaman peserta mahasiswa terhadap apa yang disampaikan oleh dosen. Model pembelajaran Problem Based Learning atau pembelajaran berbasis masalah adalah berfokus kepada Mahasiswa atau student centre. Model pembelajaran berbasis masalah tersebut memiliki cara mengenai masalahmasalah pada kehidupan pembelajaran nyata, menekankan pada kegiatan investigasi pemecahan masalah.

Pada hal ini diharapkan, mahasiswa dapat berpikir dengan mengembangkan cara berifirnya karena akan memperoleh informasi menyelesaikan setiap masalah yang dihadapi di kelas dari berbagai bentuk pemecahannya yaitu diperoleh dari diskusi dan studi pustaka tentang materi yang dipelajari. Selain itu, model pembelajaran Problem Based Learning pada setiap soal berbeda-beda. Pembagian kelompok juga dilakukan secara acak dan variatif sehingga diharapkan dapat memotivasi mahasiswa untuk berinteraksi bersama dengan siswa lainnya, tingkatkan partisipasi, saling membantu dan membantu dalam berdiskusi dan menyelesaikan masalah mereka serta berpartisipasi aktif dalam pembelajaran PKn.

Meningkatkan atau memperbaiki kualitas dalam proses pembelajaran dapat diteliti dengan tindakan kelas, peneliti melakukan refleksi terhadap permasalahan-permasalahan yang dihadapi dalam kelompok perkelompok dengan model penerapan pembelajaran Problame Based Learning (PBL).

\section{METODE PENELITIAN}

Metode penelitian yang dipilih adalah penelitian lapangan dengan objek mahasiswa dalam pembelajaran penerapan model Problem Based Learning. Analisis hasil penelitian yang diperoleh dengan menggunakan teknik analisis 
kualitatif deskriptif fenomenologis untuk menggambarkan luas dan dalamnya proses pembelajaran saat menggunakan model pembelajaran berbasis masalah. Fokus mendukung realitas atau pengalaman objek penelitian dengan memperhatikan dan memeriksa. Objek penelitian dipilih dalam penelitian ini adalah mahasiswa Universitas HKBP Nommensen Pematangsiantar dengan kriteria mahasiswa yang mengikuti kelas diskusi pendidikan kewarganegaraan.

Hasil yang didapat adalah dengan menggunakan cara observasi partisipatif, interview dimana peneliti ingin mengetahui bagaimana proses dan efektifitas pembelajaran dengan menggunakan Problem based learning serta hasil dari pembelajaran dan mendapatkan data melalui dokumentasi sebagai penunjang.

Kemudian menganalisis hasil dari metode analisis data Analisis data adalah proses pemilahan dan pengorganisasian secara sistematis sehingga Anda dapat menggunakan alat yang umum dan efektif tentang keabsahan data untuk menarik kesimpulan dari hasil penelitian yang akurat. Bandingkan dengan data. Pemeriksaan keabsahan data dilakukan dengan cara membandingkan data dari berbagai sumber, metode atau teori, sehingga dapat dilakukan dengan berbagai cara yaitu: mengusulkan berbagai kegunaan untuk menjamin keabsahan data. (Moleong, 332 )

\section{HASIL DAN PEMBAHASAN}

\section{a. Latar belakang objek penelitian}

Obyek dalam penelitian ini adalah Mahasiswa Universitas HKBP Nommensen Pematangsiantar, yakni perguruan tinggi yang dipimpin oleh ketua yang berada di bawah dan tanggung jawab langsung Yayasan Penyelenggaraan Lembaga Perguruan Tinggi Universitas HKBP Nommensen Pematangsiantar beralamatkan di Jalan Sangnahwalu No. 4, Siopat Suhu, Kecamatan Siantar Timur, Kota Pematangsiantar.

Fokus dari penelitian ini adalah mengambil mata kuliah PKn dalam program pendidikan teknologi informasi, jumlah siswa dalam mata kuliah ini adalah 40 orang yang menggunakan model pembelajaran berbasis masalah, biasanya diselesaikan dengan masalah status bukan warga negara.

\section{b. Model Pembelajaran Problem Based Learning Pada mata kuliah pendidikan kewarganegaraan}

Pembelajaran dalam kelas dengan model Problem Based Learning dapat memberikan kesempatan terhadap mahasiswa dalam berfikir mengenai masa depan masyarakat, melalui diskusi yang dapat memunculkan masalah baru untuk mencari solusi atau memunculkan ide-ide bijak dalam memilih solusi, analisis terhadap objek penelitian Madoka yang bercirikan penelitian dipengaruhi oleh berbagai faktor, seperti diskusi antar teman dan dosen. .

Dalam mata kuliah PKN, banyak pertanyaan tentang kepemimpinan nasional yang tidak sejalan dengan hak-hak rakyat. Pertanyaan yang sering dikaitkan dengan bangsa Indonesia merupakan solusi untuk meningkatkan kehidupan ekonomi dan membangun kehidupan sosial dan politik dalam masyarakat dengan budaya dan adat istiadat yang beragam. Satu masalah dapat memuat segala macam masalah, kemudian siswa mengklasifikasikan masalah tersebut ke dalam satu kategori dengan sikap pro demokrasi terhadap rakyat. Kehidupan politik di Indonesia merupakan jalan perjuangan untuk membentuk masyarakat Indonesia yang adil, makmur, maju, bahagia, dan sejahtera.

"Demokrasi" artinya rakyat. "Kratos" artinya demokrasi. Itu adalah suatu bentuk sistem pemerintahan dalam rangka mewujudkan kedaulatan rakyat. Hal itu dilakukan oleh rakyat, dan pemerintahan demokratis rakyat melaksanakan panen untuk pemerintah. . Contoh pemikiran demokratis atas isu-isu di atas antara lain: mewujudkan rasa keadilan, mengembangkan ekonomi masyarakat, menciptakan lapangan kerja seluas-luasnya, dan mengurangi standar yang memenuhi standar paket sosial yang diharapkan.

Pembahasan di Organisai mahasiswa ini membahas tentang HAM yang merupakan penyidikan hukuman mati bagi para penyelundup narkoba dan koruptor yang dianggap tidak adil dalam penyelesaian hukum. Dalam penyelesaian hukum. Di bawah bayang-bayang berdoa sambil mendoakan masalah ini, para mahasiswa membahas tentang masalah hak asasi manusia, karena hak asasi manusia di Indonesia memiliki batasan tertentu, menurut konstitusi, setiap masalah memiliki pendekatan hukum. Karena 
dapat dijelaskan bahwa hal ini untuk kepentingan ahli waris negara, dan untuk melindungi atau melindungi kehidupan orang lain.

Menurut Kansil (2016), setiap warga negara memiliki hak yang sama dalam hidup, berkeluarga dan mengeluarkan darah, mengembangkan haknya sendiri, mencari keadilan, membangun keluarga dan melanjutkan darahnya. Hak dan mencari keadilan: Mereka memiliki hak banyak pelajar yang menjadi kritik terhadap negara Indonesia, terutama kepemimpinan rakyat Indonesia, langkahlangkah untuk menjadi kaya dan korupsi yang merajalela.

Tahapan yang dilalui siswa adalah:

berikan pertanyaan

1. Mahasiswa segera menemukan temuan lain yang sesuai

2. Klarifikasi dengan teman kelompok

3. Menganalisis masalah yang disebabkan oleh metode brainstorming dan mendiskusikan fakta.

Sesuai dengan tujuan Problem Based Learning diharapkan dapat mengembangkan sikap ilmiah dari berbagai bentuk PBL yang dijelaskan oleh para ahli.Oleh karena itu, PBL biasanya dapat dilakukan melalui langkahlangkah sebagai berikut:

a. Identifikasi dan identifikasi masalah yang ada berdasarkan topik yang sedang dipelajari saat itu.

b. Analisis masalahnya, lalu ajukan pertanyaan.

c. mengajukan hipotesis

d. Pengumpulan data

e. analisis

f. Uji dugaan

g merumuskan strategi masalah

h. Menerapkan strategi manajemen masalah yang dipilih.

Dalam proses pelaksanaan pembelajaran berbasis masalah, siswa dituntut untuk berpikir kritis dan ilmiah saat melaksanakan setiap langkah pembelajaran berbasis masalah.

Dalam model pembelajaran berbasis masalah (problem based learning), penelitian masalah merupakan masalah terbuka. Dengan kata lain jawaban atas pertanyaan penelitian masih belum pasti. Setiap mahasiswa, bahkan dosen, dapat mengembangkan isi penelitian, dan memungkinkan mahasiswa untuk menggali dan menganalisis datanya secara utuh untuk menemukan solusi dari masalah tersebut.

Pembelajaran berbasis masalah merupakan peran utama mahasiswa dalam proses pembelajaran dan dipandu oleh dosen sebagai instruktur, oleh karena itu model pembelajaran ini sangat cocok untuk diterapkan dan sangat cocok digunakan di kelas pendidikan tinggi.

\section{c. Peningkatan Aktivitas Siswa Terhadap Kemampuan Pemecahan Masalah Pada Pelajaran Pendidikan Kewarganegaraan}

Pendidikan kewarganegaraan didasarkan pada filosofi pancasila untuk kesadaran demokrasi bagi masyarakat dan implementasi nyata. Dengan berlandaskan pada landasan ilmiah yaitu Dasar pemikiran pendidikan kewarganegaraan, pendidikan para pendahulu negara dan pertahanan negara yang kesemuanya berlandaskan nilai-nilai budaya dan falsafah bangsa, dan berdasarkan undang-undang yaitu UUD 1945, pembukaan UUD 1945, khususnya pada alinea kedua dan keempat Undang-Undang Dasar 1945 kemerdekaan Indonesia.

Pembelajaran kewarganegaraan lebih menitikberatkan pada pengetahuan dan pemahaman, sedangkan aspek penerapan yang lebih penting adalah nilai, karena dapat meningkatkan aktivitas aktif siswa dan membuat mereka lebih kritis dalam membangun bangsa berdasarkan peraturan perundang-undangan yang membantu membuktikan fakta dan kebenaran. Kemampuan dan keberanian untuk secara aktif mengusulkan metode pembelajaran berbasis masalah. Berdasarkan hasil penelitian, mahasiswa peneliti dapat saling berdebat dan mengkritisi diskusi yang dilakukan oleh teman dan dosen.

Hasil penelitian Redhana I. W. (2003) kesimpulannya adalah pembelajaran melalui latihan soal mampu membangun aktivitas pembelajaran dan keterampilan kunci siswa bahkan siswa. Selain itu, kemampuan siswa dalam mengidentifikasi masalah, menemukan masalah, menganalisis masalah, menganalisis masalah, menganalisis masalah, meningkatkan dan memperbaiki peningkatan aktifitas mahasiswa hal tersebut terlihat dari hasil yang dapat dipresentasikan di kelas setelah diskusi, kemudian saya menemukan seorang dosen yang mempelajari memori atau mereview topik yang 
telah dibahas.Banyak mahasiswa yang sangat menyukai model pembelajaran berbasis masalah karena dapat meningkatkan kegiatan respon siswa, dan kegiatan kelas, yang merupakan tujuan dari model pembelajaran berbasis masalah

\section{KESIMPULAN}

Berdasarkan peneliti ini, maka dapat ditarik kesimpulan sebagai berikut: Dalam kurikulum pendidikan kewarganegaraan di Sekolah Tinggi Pendidikan Normal, model pembelajaran berbasis masalah adalah sebagai berikut: Biarkan siswa memikirkan masa depan negara tentang kewarganegaraan dan mendiskusikannya. Dengan memadukan berbagai diskusi dan tanggapan antara teman dan dosen dengan sikap demokratis mahasiswa, timbul masalah baru untuk mencari solusi atau berpikir positif. Meningkatkan kemampuan siswa dalam menghadapi permasalahan di bidang pendidikan.

\section{DAFTAR PUSTAKA}

Amir Taufiq. 2009. Inovasi Pendidikan Melalui Problame Based Learning. Media Grup: Djogjakarta.

Barr, R. D., Barth, J. L., \& Shermis, S.S. (1978). The nature of the social studies. Palm spring: An ETS Pablication

Budimansyah, D. (2008). PKn dan masyarakat multikultural. Program Studi Pendidikan Kewarganegaraan, Sekolah Pascasarjana, Universitas Pendidikan Indonesia.

Chreshore (1886). " Education in The Citiziens and Civics, Vol. VII, p.2004. Dalam Yosafat, H. N. 2011. Filsafat dan Ekstrakulikuler dan Pendidkkan Kewarganegaraan. Jurnal Prospektus, Tahun IX Nomor 2, 145-158.

Kansil. 2009. Modul Pancasila dan Kewarganegaraan. PT. Pradnya Paramita: Jakarta.
Moleong, lexy, J. 2014. Metodologi Penelitian Kualitatif. Remaja Rosdakarya: Bandung.

Quigley, C. N., Buchanan, Jr. J. H., Bahmueller, C. F. (1991) Civitas : A Framework for Civic Education. Calabasas : Center for Civic Education.

Redha, I W. 2003. Meningkatkan Keterampilan Berpikir Kritis Siswa melalui pembelajaran kooperatif dengan Strategi Pemecahan Masalah. Jurnal Pendidikan dan Pengajaran IKIP Negeri Singaraja No. 3 Juli 2003.

Siahaan, K. W. A., Sinabutar, A. T., \& Haloho, u. N. (2020). Pengaruh metode quantum teaching dalam menciptakan pembelajaran yang aktif dan menyenangkan pada anak SD. Jurnal Elementaria Edukasia, 3(2).

Suwardjono, T. A. (2005). Perekayasaan Pelaporan Keuangan. Yogyakarta: BPFE.

Suryohadiprojo, Sayidiman. 2014. Mengobarkan Kembali Api Pancasila. Media Nusantara: Jakarta.

Wang, J., Fong, Y. C., \& Alwis, W. A. M. (2005). Developing professionalism in engineering students using problem based learning. Proceedings of the 2005 Regional Conference on Engineering Education, 1-9.

Winataputra, U.S. (2001). Jatidiri Pendidikan Kewarganegaraan sebagai Wahana Pendidikan Demokrasi, (Disertasi) Bandung: Universitas Pendidikan Indonesia (2006) Konsep dan Strategi Pendidikan Kewarganegaraan di Sekolah: Tinjauan Psiko-Pedagogis, Jakarta: Panitia Semiloka Pembudayaan Nilai Pancasila, Dit. Dikdas, Ditjen Mandikdasmen (Makalah). 